《Review Paper》

\title{
Remediation of Contaminated Groundwater: Change of Paradigm for Sustainable Use
}

\author{
Jin-Yong Lee ${ }^{1} \cdot$ Kang-Kun Lee ${ }^{2 *}$ \\ ${ }^{1}$ Department of Geology, Kangwon National University \\ ${ }^{2}$ School of Earth and Environmental Sciences, Seoul National University
}

\begin{abstract}
Groundwater development and use have been increasing in Korea causing frequent occurrences of related hazards such as groundwater level decline, land subsidence, and groundwater contamination. To tackle these groundwater problems, central and local governments have set-up and maintained many groundwater monitoring programs such as the National Groundwater Monitoring Network and the Groundwater Quality Monitoring Network, which collect very valuable data on the overall status of domestic groundwater to aid proper groundwater management. However, several problems mainly related to the remediation of contaminated groundwater remain unresolved. Recently, there have been some incidents related to the contamination of groundwater, and these have drawn the concern of the Korean people. Although groundwater contamination has been investigated in detail, actual groundwater remediation work has not yet been implemented. The remediation of the contaminated groundwater must begin immediately in order to sustain the ecosystem service of clean groundwater and enhance the welfare of the Korean people.
\end{abstract}

Key words : Groundwater contamination, Remediation, Sustainable use, Eco-service

\section{Introduction}

Groundwater is basically a ubiquitous resource even though the amount available varies widely with location. For a long time, Koreans have used groundwater from various sources such as shallow hand-dug wells (Woomul), community drinking water sources expecting health benefits (Yaksu), and hot springs (Oncheon) (Jeong et al., 2002; Sung, 2008; Kim et al., 2011; Lee, 2013). Nowadays, most of the Korean, from children to elderly people, consume various brands of commercial bottled groundwater (drinking Saemmul). However, many Koreans are unaware that this water has its origin in the subsurface groundwater. Furthermore, most Koreans believe that only water from mechanically drilled wells is groundwater and that drinking Saemmul (bottled groundwater) is different from the general groundwater. Even groundwater professionals and the relevant governmental officials erroneously think that the use of groundwater for drinking is low in Korea, even though they consume groundwater on a daily basis.

With rapid economic development, groundwater development and use has also been gradually growing to cater to the various demands for water supply (Lee et al., 2007; Park et al., 2011). Consequently, related hazards such as groundwater depletion (large drawdowns), land subsidence, and groundwater contamination have been often reported (Jeong, 2001; Park et al., 2005; Chae et al., 2008; Baek and Lee, 2011; Lee, 2011; Song et al., 2011). In addition, recent global climate change is expected to aggravate the groundwater condition (Woo, 2013). Further, governmental investment in groundwater conservation and management has not been sufficient.

So far, in Korea, groundwater resources have been available for free or for a very low cost, and many Koreans still do not perceive groundwater as an economic or public resource (Hahm, 2010; Kang, 2012). Furthermore, the ecoservice of clean groundwater has been disregarded. Recently, some studies have re-evaluated the eco-service of

*Corresponding author:kklee@snu.ac.kr

Received:2013.9.11 Reviewed:2013.10. 18 Accepted:2013.10.18

Discussion until : 2014.1.31 
natural resources (which were previously considered free) such as clean air, land, forest, and groundwater from an economic perspective (Bai et al., 2011; Gutrich et al., 2013; Hu et al., 2013). These studies have focused on the economic benefits of clean natural environments.

The first and official remediation of contaminated soil was undertaken in 2001 at Moonhyeon, Busan (a former military site). Since then, soil remediation efforts have been increasing and so have the relevant R\&D (Lee and Lee, 2004). However, the groundwater situation is very different. Recently, many groundwater-related accidents and/or problems have been reported, including groundwater contamination in the Chilgok (United States Forces Korea: USFK) base, the hydrofluoric acid spill in the Gumi industrial complex, the environmental concern in the foot-and-mouth disease (FMD) burial sites, the oil leaking around the Noksapyeong subway station, and groundwater contamination with organic solvents in many industrial areas. In response to these accidents, detailed investigations have been undertaken, and some of these have revealed severe groundwater contamination. However, remediation of the contaminated groundwater is not being currently implemented, and this is related to a variety of reasons encompassing political, economic, and technical issues.

In this paper, we briefly review the groundwater situation in Korea, including its development and use, its monitoring, its contamination and the remediation technologies available for contaminated groundwater. We emphasize on the need for active remediation of contaminated groundwater, irrespective of the many related obstacles, in order to sustain groundwater use and guarantee the eco-service of clean groundwater.

\section{Current Status of Groundwater in Korea}

\subsection{Groundwater Development and Use}

In Korea, data on groundwater development and use have been recorded since 1995 when the Groundwater Law (Act) was enacted (Kim et al., 1995). Fig. 1 shows annual groundwater use and the number of groundwater wells in Korea from 1996 to 2011. The number of wells continuously increased from 0.78 million (M) in 1996 to $1.44 \mathrm{M}$ in 2011, which corresponds to an increase of 38,150 wells per year.
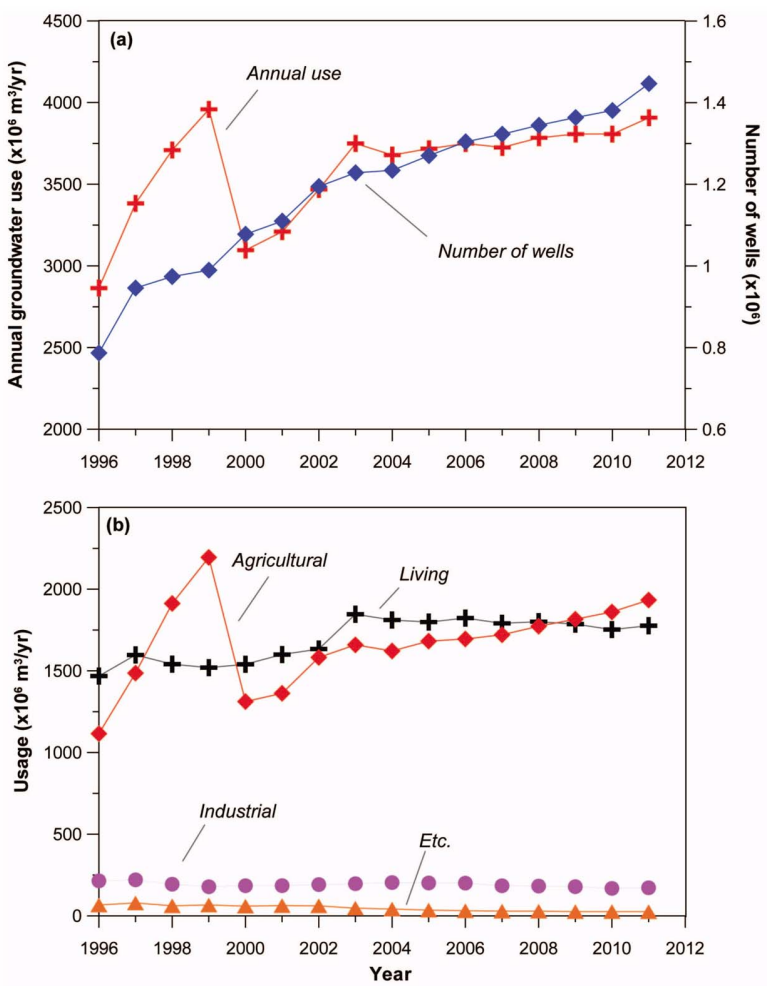

Fig. 1. Groundwater use and number of groundwater wells in Korea from 1996 to 2011. Data are from GIMS (2013).

With the increase in the number of groundwater wells, annual groundwater use also increased, except for the first four years (i.e., 1996 to 1999), from 2.86 billion (B) $\mathrm{m}^{3}$ in 1996 to $3.90 \mathrm{~B} \mathrm{~m}^{3}$ in 2011, which is equivalent to a mean increase of $65.2 \mathrm{M} \mathrm{m}^{3}$ per year. Among the total annual use, agricultural and domestic use has been dominant (Fig. 1(b)). However, in recent times, domestic groundwater use has been decreasing slightly while its use in agriculture has been increasing steadily. From this historic data for 1996 to 2011, we can expect that groundwater use in Korea will increase at least in the near future.

\subsection{Groundwater Monitoring}

There are two primary nationwide groundwater monitoring networks and a few secondary (auxiliary) monitoring networks in Korea (Table 1). The first primary network is the National Groundwater Monitoring Network (NGMN), which has been managed by the Ministry of Land and Transport, and the Korea Water Resources Corporation (KWater) since 1995, and it mainly monitors groundwater quantity nationwide (Kim et al., 1995; Lee et al., 2007). As 
Table 1. Summary of groundwater monitoring networks (stations) in Korea (as of 2011; modified from Lee et al. (2007))

\begin{tabular}{|c|c|c|}
\hline Monitoring network & Number of wells & Management/operation \\
\hline $\begin{array}{l}\text { National Groundwater Monitoring Network } \\
(\mathrm{NGMN})\end{array}$ & 497 & Ministry of Land and Transport/K-Water \\
\hline Groundwater Quality Monitoring Network (GQMN) & 2,579 & Ministry of Environment/KECO \\
\hline $\begin{array}{l}\text { Subsidiary Groundwater Monitoring Network } \\
\text { (SGMN) }\end{array}$ & $\begin{array}{c}10,000 \\
\text { (target number) }\end{array}$ & Local governments like Seoul and Jeju \\
\hline Seawater Intrusion Monitoring Network (SIMN) & 117 & Ministry for Food, Agriculture, Forestry and Fisheries/KR (as of 2012) \\
\hline Drinking Water Monitoring Network (DWMN) & not known & Ministry of Environment \\
\hline
\end{tabular}

of 2011, there were 336 monitoring stations (497 monitoring wells) under NGMN, covering the whole country including Jeju Island. Many of these stations have two monitoring wells, one for shallow groundwater and the other for deep bedrock groundwater. The monitoring equipment installed in each well measures groundwater level, electrical conductivity, and water temperature every hour. The measured data are automatically transferred to K-Water. Using the monitored data, K-Water analyzes trends in groundwater parameters (Park et al., 2011), which are then reflected in the national management plan for groundwater resources.

The other primary monitoring network is the Groundwater Quality Monitoring Network (GQMN), which mainly monitors changes in groundwater quality, and it is managed by the Ministry of Environment. The GQMN is comprised of the National Groundwater Quality Monitoring Network (NGQMN), the Regional Groundwater Quality Monitoring Network (RGQMN), the NGMN, and the Seawater Intrusion Monitoring Network (SIMN). In 2011, a total of 2,579 wells were examined for groundwater quality. In the monitoring, groundwater sampling and subsequent chemical analyses were conducted two times (April-May and SeptemberOctober) per year. A total of 20 parameters were analyzed including contents of nitrate, chloride, total coliform, TCE, and PCE.

The secondary groundwater monitoring network includes the Subsidiary Groundwater Monitoring Network (SGMN) operated by local governments such as Seoul, Busan, Daegu and Incheon, and Jeju island (Lee et al., 2005; Kim et al., 2007; Choi and Lee, 2012; GIMS, 2013). The SGMN surveys groundwater level at one to three times per month and groundwater quality two times per year. Other secondary groundwater monitoring networks like the Seawater Intrusion Monitoring Network (SIMN) and the Drinking Water
Monitoring Network (DWMN) have specific goals. The SIMN, operated by the Ministry of Agriculture, Food and Rural Affairs and the Korea Rural Community Corporation, is mostly comprised of multi-level wells installed in islands and coastal areas, especially facing the Yellow Sea and the South Sea (Song et al., 2007). As of 2012, a total of 117 monitoring wells were operating (MIFAFF and KR, 2012; Park et al., 2013).

All this monitoring data facilitates the understanding of the groundwater condition in Korea. Using this data, we found various facts about the condition of the domestic groundwater which are:

1) The groundwater level was generally decreasing during 1996 to 2008.

2) The majority of ground water temperatures recorded during 1996 to 2008 showed increases at rates of 0.04 to $0.09^{\circ} \mathrm{C}$ per year due to global warming or climate change (Lee et al., 2006; Park et al., 2011).

3) 41 to $50 \%$ of the coastal groundwater was affected by seawater intrusion (Park et al., 2012).

It has been shown that groundwater in some urban areas is severely contaminated with various organic compounds (Park et al., 2005; Lee et al., 2010; Baek and Lee, 2011). From analyses of the data and results, we acknowledge that the groundwater monitoring programs are functioning appropriately.

\subsection{Groundwater Contamination}

With increasing public concern regarding groundwater contamination, relevant investigations have been widely conducted (Lee, 2011). Here, we review two significant groundwater contamination accidents and draw relevant implications.

Groundwater contamination with organic solvents, espe- 


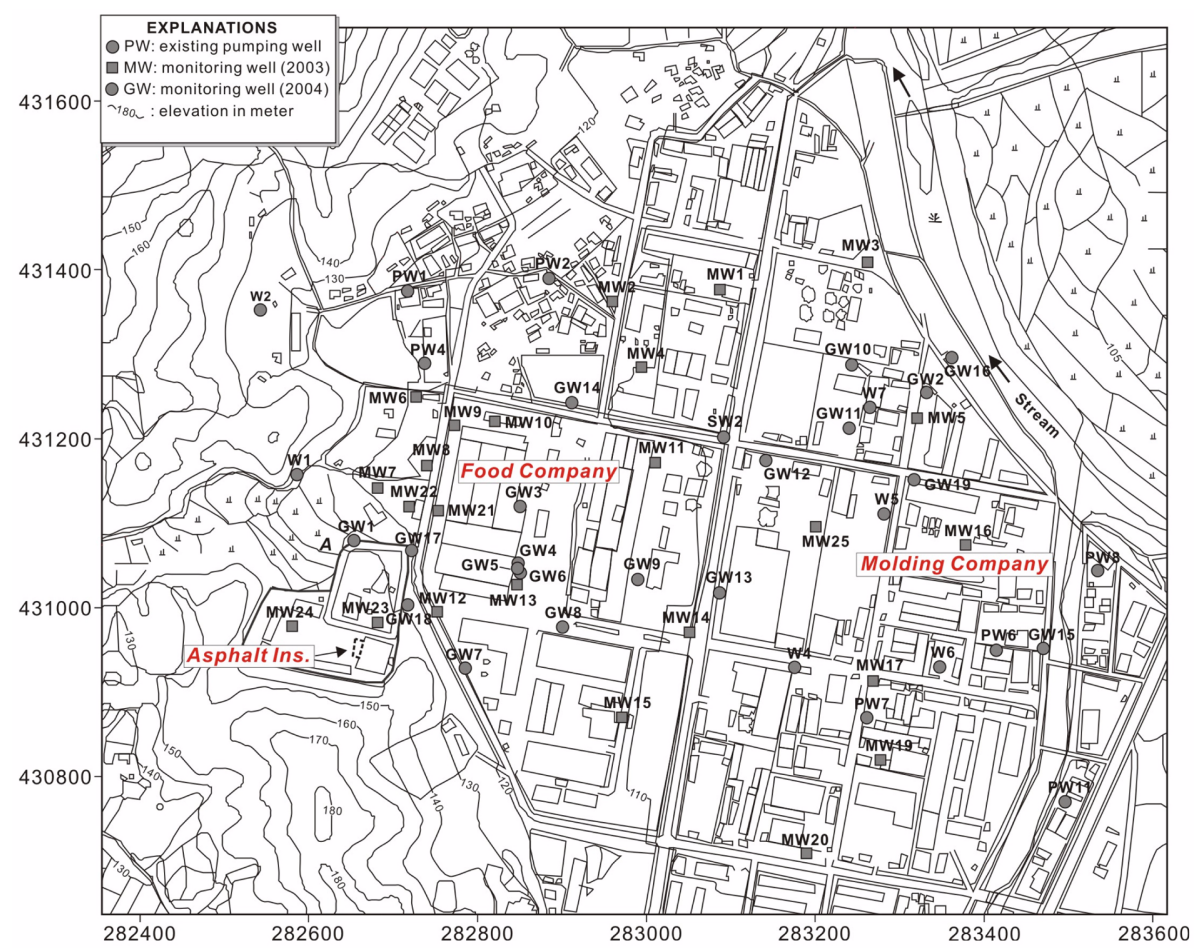

Fig. 2. Location of the TCE contaminated site in Wonju, showing the locations of the asphalt test institute and the molding company. Modified from Baek and Lee (2011).

cially TCE, in an industrial complex of Wonju city was first found from a groundwater quality monitoring network (GQMN) survey in 1995 (Yu et al., 2006; Baek and Lee, 2011). Successive detailed investigations revealed that groundwater contamination was severe and widespread in most of the industrial area, and the contaminants of concern, in addition to TCE, also included PCE, CT and CF (Baek and Lee, 2011; Yang et al., 2012). Yu et al. (2006) designated the Asphalt Test Institute of the Gangwon Road Maintenance Office (GRMO), located upgradient of the complex, as the contamination source (Fig. 2) based on topography, hydrogeology, TCE use history, and soil contamination. The contaminated soil within the GRMO was remediated using a low thermal desorption method (Jo et al., 2010). However, a practical remediation of the contaminated groundwater has not been undertaken so far.

There are some technical problems behind not carrying out the remediation. The most important issue is about the apportionment of the TCE contamination. Apart from the Asphalt Test Institute, there are also other plausible sources of contamination of the groundwater such as a molding company, even though they are not expected to contribute to the con- tamination to a great extent (Baek and Lee, 2011; Yang and Lee, 2012). Although it is practically obvious that the Asphalt Test Institute is the main source of the TCE contaminated groundwater at this site, the GRMO has not admitted responsibility for the contamination and has continuously suspended the remediation work of the contaminated groundwater.

Another important groundwater contamination accident was the oil (a mixture of a little part of gasoline and a majority of kerosine) spill in the sump of the Noksapyeong subway station (line \#6), which is widely known from the mass media. From detailed investigations by both the Korean and the US sides, which factored in topography, hydrogeology, groundwater flow and contaminant analysis, it was recognized that the gasoline component was derived from the south post of the Yongsan Garrison (Fig. 3). However, there is still a dispute about the origin of the kerosine (nearly same with JP-8) in the subway (the US side denies its origin is from the garrison) even though the hydrogeologic conditions all indicate that the most plausible source is the garrison (Segye Daily, 2004).

The Seoul metropolitan government has conducted a response work (basically pump and treat, but the details are 


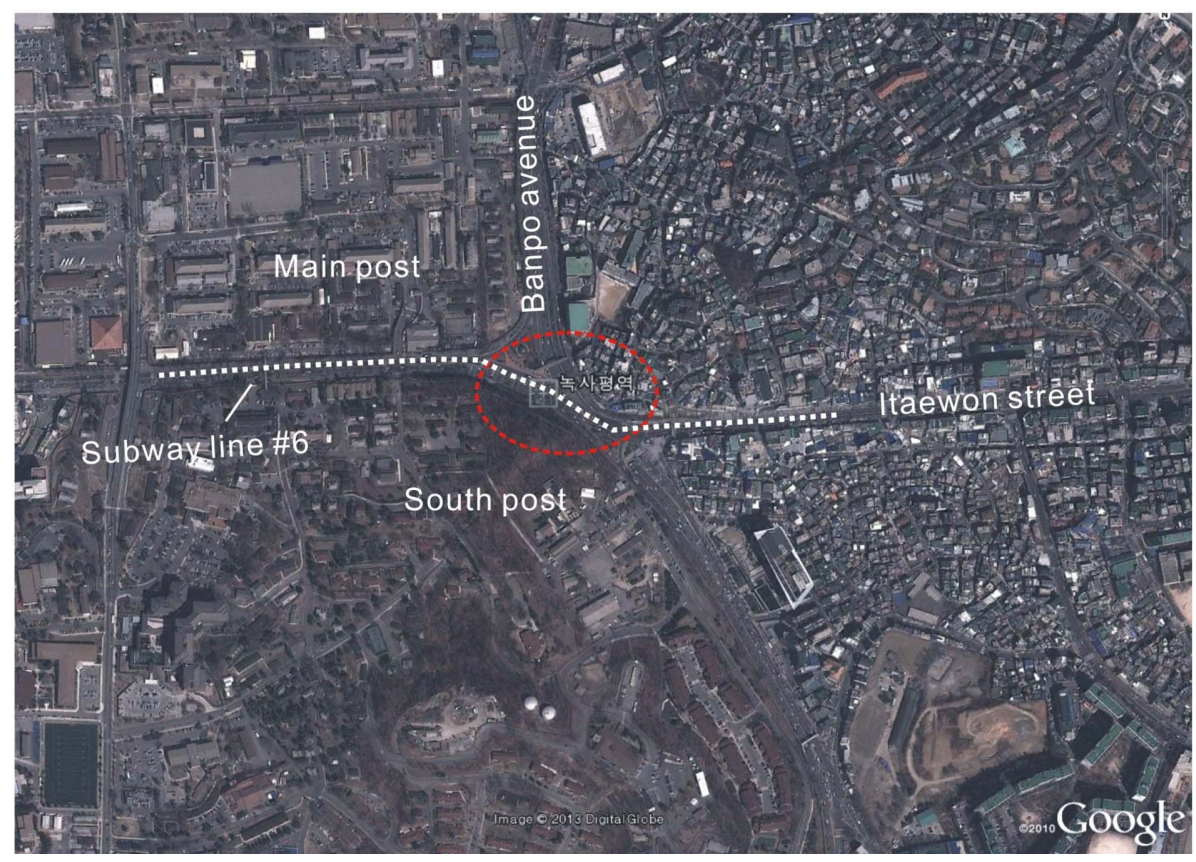

Fig. 3. Location of Noksapyeong station of the metropolitan subway line \#6. The base map is from Google.

unknown) for the contaminated groundwater found outside of the US base since 2001. However, contaminated groundwater exceeding Korean standards and some free product are still occurring (CBS Nocut, 2013). The unsuccessful remediation can be attributed to incomplete source removal and remedial works inside the US base. All these technical and political situations have complicated and suspended the remediation of the contaminated groundwater.

\section{Remediation Technologies for Contaminated Groundwater in Korea}

It is difficult to discuss remediation technologies for contaminated groundwater because there have not many groundwater remediation projects in Korea (Lee et al., 2012), and if any, most of them have been treated as subsidiary work of the main soil remediation projects. A few mass media articles reported that bioslurping technology was applied as a response action for the petroleum contaminated groundwater and free product in some of USFK bases including Camp Page in Chuncheon and Yongsan Garrison in Seoul (Gangwon Daily, 2006; Yonhap News, 2007). Bioslurping is an integrated remediation method that simultaneously treats contaminated groundwater, free product, and hydrocarbon vapor in the subsurface by supplying vacuum (Baker and Bierschenk, 1996; Yen and Chang, 2003). However, the effectiveness of the bioslurping system for contaminated groundwater has not been examined in Korea.

There have been few research projects for developing remediation technologies of contaminated groundwater suitable for Korean hydrogeologic conditions. A field based research project to develop methods for treating DNAPL contaminated groundwater began recently in Wonju (Baek and Lee, 2011; Lee et al., 2012; Yang et al., 2012). In this research project, a cost-effective pump-and-treat technology, a combined bioaugmentation and cosolvent/surfactant flushing technology for hot source zone, and an integrated advanced oxidation and bioremediation technology for dispersed DNAPL plume have been studied (Lee, 2010). After the field demonstration, the remediation technologies for contaminated groundwater that have been developed will be practically applied in real sites, including the Wonju site.

\section{Conclusion}

We have briefly reviewed the groundwater situation in Korea. Although there have been substantial developments in groundwater investigation, monitoring, and management, 
several problems remain unresolved. Although the knowledge and methods for determining the origin of groundwater contamination (environmental forensics), apportioning the responsibility of the contamination, and cleaning the contaminated groundwater are not enough, the remediation of contaminated groundwater must begin as soon as possible. This remediation will help sustain the eco-system service of clean groundwater and enhance the welfare of the Korean people in the 21 st century. In order to accomplish this purpose, institutional and legislative supports are essentially required.

\section{Acknowledgements}

This research is supported by the Korean Ministry of Environment as "The GAIA project (No. 173-092-010)". The authors greatly appreciate the helpful comments by three anonymous reviewers.

\section{References}

Baek, W. and Lee, J.Y., 2011, Source apportionment of trichloroethylene in groundwater of an industrial complex in Korea: a 15-year dispute and perspective, Water Environ. J., 25(3), 336344.

Bai, Y., Wang, R., and Jin, J., 2011, Water eco-service assessment and compensation in a coal mining region-A case study in the Mentougou District in Beijing, Ecol. Complex., 8(2), 144152.

Baker, R.S. and Bierschenk, J., 1996, Bioslurping LNAPL contamination, Pollut. Engrg., 28(3), 109-114.

CBS Nocut, 2013, Messy Yongsan Garrison, June 20, 2013 (in Korean).

Chae, G.T., Yun, S.T., Choi, B.Y., Yu, S.Y., Jo, H.Y., Mayer, B., Kim, Y.J., and Lee, J.Y., 2008, Hydrochemistry of urban groundwater, Seoul, Korea: the impact of subway tunnels on groundwater quality, J. Contam. Hydrol., 101(1-4), 42-52.

Choi, H.M. and Lee, J.Y., 2012, Changes of groundwater conditions on Jeju volcanic island, Korea: implications for sustainable agriculture, Afr. J. Agri. Res., 7(4), 647-661.

Gangwon Daily, 2006, Dispute on remediation technology of contaminated US base, August 1, 2006 (in Korean).

GIMS (National Groundwater Information Management and Service Center), 2013, Homepage of GIMS, http://www.gims. go.kr.

\section{J. Soil \& Groundwater Env. Vol. 18(6), p. 1 7, 2013}

Gutrich, J.J., Gigliello, K., Vest, K., and Elmore, A., 2013, Water, native plant communities, and air quality in Owens Valley, California (USA): an ecological-economic analysis of groundwater management sustaining alkali meadow communities, 15th International BIOECON Conference, Cambridge, UK, $43 \mathrm{p}$.

Hahm, T.S., 2010, A legal study on systematic conservation, management of groundwater, Environ. Law Res., 32(1), 475-507 (in Korean with English abstract).

Hu, X., Wu, C., Hong, W., Qiu, R., and Qi, X., 2013, Impact of landuse change on ecosytem service values and their effects under different intervention scenarios in Fuzhou City, China, Geosci. J. (in press).

Jeong, C.H., 2001, Effect of land use and urbanization on hydrochemistry and contamination of groundwater from Taejon area, Korea, J. Hydrol., 253(1-4), 194-210.

Jeong, C.H., Park, C.H., and Lee, K.S., 2002, Water quality and hydrochemistry of natural springs and community wells in Daejeon area, Econ. Environ. Geol., 35(5), 395-406 (in Korean with English abstract).

Jo, Y.J., Lee, J.Y., Yi, M.J., Kim, H.S., and Lee, K.K., 2010, Soil contamination with TCE in an industrial complex: contamination levels and implication for groundwater contamination, Geosci. J., 14(3), 313-320.

Kang, I.S., 2012, A study on the legal nature of water resources, J. Water Policy Econ., 19, 107-118 (in Korean with English abstract).

Kim, J.W., Lee, J.Y., Yi, M.J., Kim, G.B., Won, J.H., and Lee, K.K., 2007, Allocating local groundwater monitoring stations for South Korea using an analytic hierarchy process, Hydrogeol. J., 15, 615-632.

Kim, K.R., Gil, H.K., Lee, M.H., Eom, S.W., and Lee, J.Y., 2011, Survey of citizens public opinion for natural spring water in Seoul, J. Soil Groundwater Env., 16(2), 1-5 (in Korean with English abstract).

Kim, N.J., Cho, M.J., and Woo, N.C., 1995, Developing a national groundwater monitoring network in Korea, Hydrogeol. J., 3(4), 89-94.

Lee, J.Y., 2011, Environmental issues of groundwater in Korea: implications for sustainable use, Environ. Conserv., 38(1), 6474.

Lee, J.Y., 2013, Debate on a healthy drinking water: belief or science?, Environ. Sci. Europe (submitted).

Lee, J.Y., Choi, M.J., Kim, Y.Y., and Lee, K.K., 2005, Evaluation of hydrologic data obtained from a local groundwater monitoring network in a metropolitan city, Korea, Hydrol. Process., 19(13), 2525-2537. 
Lee, J.Y. and Lee, K.K., 2004, A short note on investigation and remediation of contaminated groundwater and soil in Korea, $J$. Engrg. Geol., 14(1), 123-130 (in Korean).

Lee, J.Y., Moon, S.H., and Yun, S.T., 2010, Contamination of groundwater by arsenic and other constituents in an industrial complex, Environ. Earth Sci., 60, 65-79.

Lee, J.Y., Yi, M.J., Lee, J.M., Ahn, K.H., Won, J.H., Moon, S.H., and Cho, M., 2006, Parametric and non-parametric trend analysis of groundwater data obtained from national groundwater monitoring stations, J. KoSSGE, 11(2), 56-67 (in Korean with English abstract).

Lee, J.Y., Yi, M.J., Yoo, Y.K., Ahn, K.H., Kim, G.B., and Won, J.H., 2007, A review of national groundwater monitoring network (NGMN) in Korea, Hydrol. Process., 21(7), 907-919.

Lee, K.K., 2010, Welcome remarks and about SEEDS, 2010 SEEDS Workshop and External Review Meeting on DNAPL Remediation Research (GAIA Project), Seoul, pp. 1-4.

Lee, K.K., Cheon, J.Y., Yi, M.J., Lee, J.Y., Jun, S.C., Kwon, H.P., Park, Y.C., and Kim, Y.C., 2012, A technology analysis report on pump-and-treat, KEITI, 68 p. (in Korean)

MIFAFF (Ministry for Food, Agriculture, Forestry and Fisheries) and KR (Korea Rural Community Corporation), 2012, An Investigation Report on Seawater Intrusion, KR, Uiwang, 764 p.

Park, Y., Lee, J.Y., Kim, J.H., and Song, S.H., 2012, National scale evaluation of groundwater chemistry in Korea coastal aquifers: evidence of seawater intrusion, Environ. Earth Sci., 66, 707-718.

Park, Y., Song, S.H., Lee, J.Y., and Kim, J.H., 2013, Salinization and desalinization of western and southern coastal groundwaters of Korea, Earth Environ. Sci. Trans. Royal Soc. Edinburgh (submitted).

Park, Y.C., Jo, Y.J., and Lee, J.Y., 2011, Trends of groundwater data from the Korean National Groundwater Monitoring Stations: indication of any change?, Geosci. J., 15(1), 105-114.

Park, S.S., Kim, S.O., Yun, S.T., Chae, G.T., Yu, S.Y., Kim, S., and Kim, Y., 2005, Effects of land use on the spatial distribution of trace metals and volatile organic compounds in urban ground- water, Seoul, Korea, Environ. Geol., 48(8), 1116-1131.

Segye Daily, 2004, How much was groundwater contaminated at Noksapyeong?, October 31, 2004 (in Korean).

Song, S.H., Lee, G.S., Um, J.Y., and Suh, J.J., 2011, Resistivity imaging using borehole electrical resistivity tomography: a case of land subsidence in karst area due to the excessive groundwater withdrawal, J. Kor. Earth Sci. Soc., 32(6), 537-547 (in Korean with English abstract).

Song, S.H., Lee, J.Y., and Yi, M.J., 2007, Evaluation of longterm data obtained from seawater intrusion monitoring network using variation type analysis, J. Kor. Earth Sci. Soc., 28(4), 478490 (in Korean with English abstract).

Sung, I.H., 2008, Sustainable development plan of groundwater for drinking water-Propose to the Pan-nationwide campaign through "The Restoration of Abandoned Village Wells to Drinkable", J. KoSSGE, 13(3), 1-7 (in Korean).

Woo, N.C., 2013, Climate change and groundwater sustainability in Korea for next decade, J. Soil Groundwater Env., 18(1), 15 (in Korean with English abstract).

Yang, J.H. and Lee, K.K., 2012, Locating plume sources of multiple chlorinated contaminants in groundwater by analyzing seasonal hydrological responses in an industrial complex, Wonju, Korea, Geosci. J., 16(3), 301-311.

Yang, J.H., Lee, K.K., and Clement, T.P., 2012, Impact of seasonal variations in hydrological stresses and spatial variations in geologic conditions on a TCE plume at an industrial complex in Wonju, Korea, Hydrol. Process., 26, 317-325.

Yen, H.K. and Chang, N.B., 2003, Bioslurping model for assessing light hydrocarbon recovery in contaminated unconfined aquifer. II: Optimization analysis, Pract. Period. Hazard. Toxic Radioact. Waste Manage., 7(2), 131-138.

Yonhap News, 2007, Return of 9 US military bases: issue of environmental problems, June 1, 2007 (in Korean).

Yu, S.Y., Chae, G.T., Jeon, K.H., Jeong, J.S., and Park, J.G., 2006, Trichlotoethylene contamination in fractured bedrock aquifer in Wonju, South Korea, Bull. Environ. Toxicol., 76, 341348. 